\title{
High occurrence of Calodium hepaticum (syn. Capillaria hepatica) spurious infection in a village in the Atlantic Forest of southern Brazil
}

\author{
Débora do Rocio Klisiowicz ${ }^{1,2} /{ }^{+}$, Larissa Reifur ${ }^{1,2}$, Márcia Kiyoe Shimada ${ }^{1}$, \\ Juciliane Haidamak ${ }^{2}$, Regielly Caroline Raimundo Cognialli², Tatiane Ferreira ${ }^{2}$ \\ 1Departamento de Microbiologia, Parasitologia e Patologia ²Programa de Pós-Graduação em Microbiologia, \\ Parasitologia e Patologia, Universidade Federal do Paraná, Curitiba, PR, Brasil
}

Calodium hepaticum (syn. Capillaria hepatica) is a nematode of the Capillariidae family that infects rodents and other mammals. In Brazil, human spurious infections of $\mathrm{C}$. hepaticum have been detected in indigenous or rural communities from the Amazon Basin, but not in the southern states of the country. Here, we report the highest occurrence (13.5\% of 37 residents) of $\mathrm{C}$. hepaticum human spurious infection detected in Brazil and the first record in a southern region, Guaraqueçaba. The finding is explained by the area being located in the Atlantic Forest of the state of Paraná, surrounded by preserved forests and because the inhabitants consume the meat of wild mammals.

Key words: Calodium hepaticum - Capillaria hepatica - human spurious infection - Brazil - Paraná

The family Capillariidae of parasites (Bancroft 1893) is composed of approximately 300 worldwide-distributed species, with three occasionally infecting humans: Calodium hepaticum, Paracapillaria (Crossicapillaria) philippinensis and Eucoleus aerophilus. C. hepaticum (Bancroft, 1893), also known as Capillaria hepatica, is a parasitic nematode with a cosmopolitan distribution that infects several mammals, including humans (Galvão 1981, Fuehrer et al. 2011).

There are two types of infections caused by $C$. hepaticum: hepatic infection and spurious infection. The spurious infection occurs following the ingestion of unembryonated eggs that pass through the digestive tract and are eliminated in the faeces (Galvão 1981). In the hepatic infection, also called the true infection, after ingestion of embryonated eggs by a mammal, the larvae hatch, penetrate through the intestinal wall, migrate into the hepatic portal system and develop into adults in the hepatic parenchyma. Immature eggs are released in the liver parenchyma after approximately 28 days and will only reach the environment after the death and decomposition of the host or when the host becomes prey. Humans are among such predators and therefore acquire the spurious infection after ingesting unembryonated eggs present in the liver of infected game or the soil. In this case, the unembryonated eggs pass through the digestive tract and are shed in the faeces. Under suitable conditions of temperature and humidity, the eggs in soil will embryonate in approximately five-seven weeks and, if ingested, will be responsible for the true infection (Bancroft 1893, Lee 1964, Farhang-Azad 1977, Galvão 1981).

doi: 10.1590/0074-0276140315

+ Corresponding author: deborak@ufpr.br

Received 13 June 2013

Accepted 29 November 2013
To the best of our knowledge, there are 72 worldwide cases of human hepatic calodiasis (syn. hepatic capillariasis) described in the literature (Fuehrer et al. 2011), five of which were reported from Brazil (Piazza et al. 1963, Pereira \& França 1981, Sawamura et al. 1999). In contrast, among the 135 worldwide cases of human spurious infection, 94 are from Brazil, reported from Amazon (Coimbra Jr \& Mello 1981, Santos et al. 1985, 1995, Carvalho-Costa et al. 2009, Hinke 2009, Palhano-Silva et al. 2009, Camargo et al. 2010, Soares et al. 2011, Gonçalves et al. 2012) and the state of Minas Gerais (Machado et al. 2008). The other spurious cases were detected in Panama, French Guinea, Taiwan, Russia, the United States of America and Zimbabwe (Fuehrer et al. 2011). Despite the fact that hepatic and spurious infections have been reported in Brazil, all cases are from the northern, northeastern or central parts of the country where a tropical climate is observed. Indeed, nothing is known about its presence in southern Brazil, a region where the climate is temperate.

The area of this study is a small village within Guaraqueçaba, a coastal city of $2,315 \mathrm{~km}^{2}$ in the state of Paraná (PR), southern Brazil. It is relevant to mention that the current Guaraqueçaba residents maintain old habits from the indigenous tribes that once inhabited the region. In addition and to preserve the natural patrimony, the city authorities created many conservation units; with approximately 8,000 current inhabitants, the city is characterised by many green and protected areas where it is possible to find small isolated villages (data obtained from the city website). In the village selected for this study, mainly due to a lack of sanitation facilities, it was common for several residents to defecate directly on the soil in domestic surroundings. There was no potable water and their water supply was directly from the river located approximately $20 \mathrm{~m}$ from the homes. The village was composed of seven families, totalling 39 residents; 37 agreed to participate, a surprisingly high acceptance rate $(95 \%)$. The faecal samples donated by the 37 participants (23 males and 14 female, ages ranging from 11 
months to 61 years) were processed using a zinc sulphate centrifugation-floatation method (Faust et al. 1938) and spontaneous sedimentation (Hoffman et al. 1934). Three slides were prepared from each method per sample, stained with Lugol's iodine and examined by two investigators. The study was conducted in spring (September) 2001, with approval by the Federal University of Paraná (UFPR) Research Ethical Committee, registered under the protocol 038ext020/201-07.

Eggs compatible with $C$. hepaticum (Supplementary data), as previously described by Galvão (1981) and Li et al. (2010), were detected in the faecal samples of five adults ( 3 male and 2 female), accounting for $13.5 \%$ of the residents. The intradomiciliary rates of infection for the two families were $50 \%$ and $28.5 \%$. However, none of the infected individuals showed clinical signs of digestive problems. This is the highest occurrence reported in Brazil since Soares et al. (2011) and Gonçalves et al. (2012), with rates of $8.6 \%$ and $6.7 \%$, respectively. From the positive samples, 30 eggs were measured and ranged $58-63 \mu \mathrm{m}$ in length [standard deviation $(\mathrm{SD})=2.33$ ] and $31-36 \mu \mathrm{m}$ in width $(\mathrm{SD}=1.47)$, averaging $60 \mu \mathrm{m} \times 34 \mu \mathrm{m}$. Other intestinal parasite eggs or cysts were also found, including $40.5 \%$ Ascaris lumbricoides, $16.2 \%$ hookworms, 35.1\% Enterobius vermicularis, 2.7\% Giardia duodenalis, 32.4\% Entamoeba coli, 29.7\% Endolimax nana and $29.7 \%$ Iodamoeba bütschlii.

To understand the source of contamination, an interview was conducted with the participants and it was revealed that the ingestion of the meat and viscera wild mammals was a frequent habit. Furthermore, all the infected people confessed having eaten anteater meat and viscera the night before the faecal collection, which could explain the presence of $C$. hepaticum eggs in their faeces. To our knowledge, anteaters have not been incriminated as hosts for C. hepaticum, but the consumption of infected liver tissue from wild mammals, such as tapir, paca, agouti and peccary, has been suggested in the literature as a probable source of contamination for human spurious infection (Carvalho-Costa et al. 2009, Camargo et al. 2010) and peccary hepatic infection, as confirmed by Gonçalves et al. (2012).

In summary, we detected for the first time the presence of C. hepaticum eggs in faecal samples from humans living in southern Brazil. Further investigations are necessary to determine the parasite dispersion pattern and the presence of hosts with the true infection. Taking into consideration the existing scenario, it is likely that the hepatic infection is present among the same residents or wild mammals. The river and soil around the households could be contaminated with embryonated eggs and thus be an important source for the true infection in humans and wild mammals. Human hepatic calodiasis has a poor prognosis, is often fatal and is associated with eosinophilia, fever, hepatosplenomegaly, granulomatous hepatitis, liver fibrosis and haemorrhage (Galvão 1981, Camargo et al. 2010), representing a serious public health problem. It was not the purpose of this study, but epidemiological and immunological studies should be performed on the rural populations living in Guaraqueçaba and the surrounding coastal areas of PR to determine the existence of hepatic calodiasis in humans.

C. hepaticum infections are typically associated with the Brazilian Amazon; however, in this study, we show that other geographical areas outside the Amazon can also be suitable for a high occurrence of these infections. Even thousands of kilometres away from the Brazilian Amazon, Guaraqueçaba is an example, showing preserved forests within the remaining Atlantic Forest biome. In addition, its inhabitants maintain the eating habits of ingesting the meat and liver of wild mammals and there is a lack of sanitary conditions, all of which favour the life cycle of the parasite.

\section{ACKNOWLEDGEMENTS}

To the Interdisciplinary Centre for Environment and Development, UFPR, and the Guaraqueçaba city council who supported our work.

\section{REFERENCES}

Bancroft TL 1893. On the whipworm of the rat's liver. J Proc $R$ Soc NSW 27: 89-90.

Camargo LMA, Camargo JSAA, Vera LJS, Barreto PTC, Tourinho EK, Souza MM 2010. Capillariaisis (Trichurida, Trichinellidae, Capillaria hepatica) in the Brazilian Amazon: low pathogenicity, low infectivity and a novel mode of transmission. Parasit Vectors 3: 1-6.

Carvalho-Costa FA, Silva AG, Souza AH, Moreira CJ, Souza DL, Valverde JG, Jaeger LH, Martins PP, Meneses VF, Araújo A, Boia MN 2009. Pseudoparasitism by Calodium hepaticum (syn. Capillaria hepatica; Hepaticola hepatica) in the Negro River, Brazilian Amazon. Trans R Soc Trop Med Hyg 103: 1071-1073.

Coimbra Jr CEA, Mello DA 1981. Enteroparasitas e Capillaria sp. entre o grupo Suruí, Parque Indígena de Aripuanã, Rondônia. Mem Inst Oswaldo Cruz 76: 299-302.

Farhang-Azad A 1977. Ecology of Capillaria hepatica (Bancroft 1893) (Nematoda). II. Egg-releasing mechanisms and transmission. J Parasitol 63: 701-706.

Faust EC, D’Antoni JS, Odom V, Miller MJ, Peres C, Sawitz W, Thomen LF, Tobie J, Walker JH 1938. A critical study of clinical laboratory technics for the diagnosis of protozoan cysts and helminth eggs in feces: in preliminary communication. Am J Trop Med Hyg 18: 169-183.

Fuehrer HP, Igel P, Auer H 2011. Capillaria hepatica in man - an overview of hepatic capillariosis and spurious infections. Parasitol Res 109: 969-979.

Galvão VA 1981. Estudos sobre Capillaria hepatica: uma avaliação do seu papel patogênico para o homem. Mem Inst Oswaldo Cruz 76: 415-433.

Gonçalves AQ, Ascaso C, Santos I, Serra PT, Juliao GR, Orlandi PP 2012. Calodium hepaticum: household clustering transmission and the finding of a source of human spurious infection in a community of the Amazon Region. PLoS Negl Trop Dis 6: 1-6.

Hinke TZ 2009. Perfil nosológico da população ribeirinha do baixo Rio Machado em Rondônia/Amazônia Ocidental - Brasil, PhD Thesis, Universidade de São Paulo, São Paulo, 49 pp.

Hoffman WA, Pons JA, Janer JL 1934. The sedimentation-concentration method in shistosomiasis mansoni. J Public Health 9: 283-298.

Lee CW 1964. The experimental studies on Capillaria hepatica. Korean J Parasitol 2: 63-77. 
Li CD, Yang HL, Wang Y 2010. Capillaria hepatica in China. World J Gastroenterol 16: 698-702.

Machado ER, Santos DS, Costa-Cruz JM 2008. Enteroparasites and commensals among children in four peripheral districts of Uberlândia, state of Minas Gerais. Rev Soc Bras Med Trop 41: 581-585.

Palhano-Silva CS, Araújo AJG, Lourenço AEP, Bastos ONP, Santos RV, Coimbra Jr CEA 2009. Intestinal parasitic infection in the Suruí Índians, Brazilian Amazon. Interciência 34: 259-264.

Pereira VG, França LC 1981. Human Capillaria hepatica infection. Report of a case treated successfully. Rev Hosp Clin Fac Med Sao Paulo 36: 31-34.

Piazza R, Correa MO, Fleury RN 1963. On a case of human infestation with Capillaria hepatica. Rev Inst Med Trop Sao Paulo 5: 37-41.
Santos RV, Coimbra Jr CE, Flowers NM, Silva JP 1995. Intestinal parasitism in the Xavánte Indians, Central Brazil. Rev Inst Med Trop Sao Paulo 37: 145-148.

Santos RV, Coimbra Jr CEA, Ott AMT 1985. Estudos epidemiológicos entre grupos indígenas de Rondônia. III. Parasitoses intestinais nas populações dos vales dos rios Guaporé e Mamoré. Cad Saude Publica 1: 467-477.

Sawamura R, Fernandes MI, Peres LC, Galvão LC, Goldani HA, Jorge SM, Melo Rocha G, Souza NM 1999. Hepatic capillariasis in children: report of 3 cases in Brazil. Am J Trop Med Hyg 61: 642-647.

Soares MCP, Nunes HM, Silveira FAA, Alves MM, Souza AJS 2011. Capillaria hepatica (Bancroft, 1893) (Nematoda) entre populações indígenas e mamíferos silvestres no noroeste do estado do Mato Grosso, Brasil, 2000. Rev Pan-Amaz Saude 2: 35-40. 


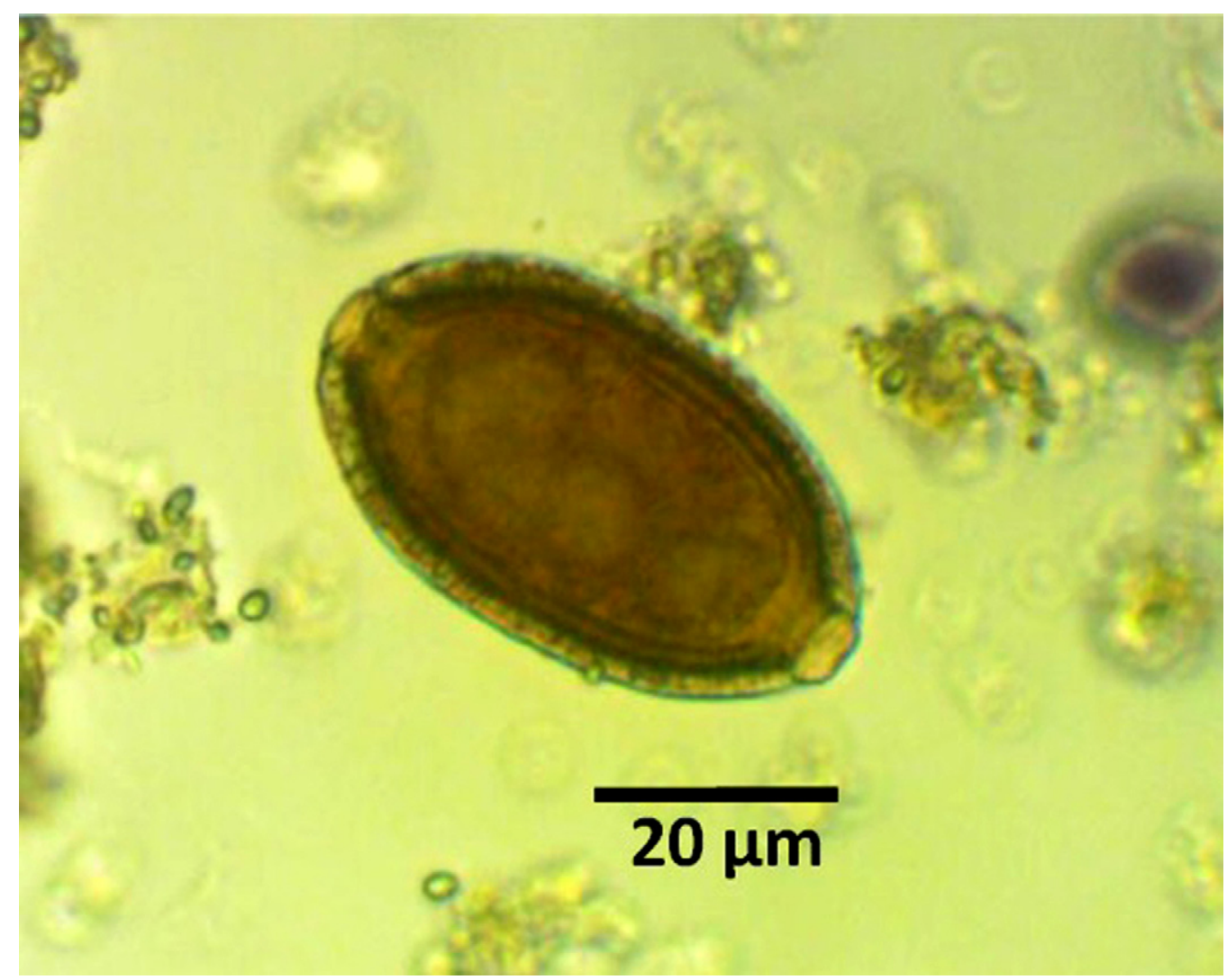

Calodium hepaticum egg recovered from a faecal sample of a resident from the city of Guaraqueçaba, state of Paraná, Brazil. 